\title{
Assessment of Salmonella spp. and Mold-Yeast Contamination in Packaged and Unpackaged Spices
}

\author{
Ayşe Hümeyra İslamoğlu*, B. İrem Omurtag Korkmaz \\ Marmara University Faculty of Health Sciences, Nutrition and Dietetics Department.
}

\begin{abstract}
In this study packaged $(\mathrm{n}=15)$ and unpackaged $(\mathrm{n}=15)$ spices including black pepper, oregano, peppermint, red pepper, cinnamon were collected and analyzed microbiologically. Mold-yeast contents of packaged samples were $1.07 \times 10^{4} \mathrm{cfu} / \mathrm{g}$ in red pepper, $1.75 \times 10^{4} \mathrm{cfu} / \mathrm{g}$ in black pepper, $7.72 \times 10^{4} \mathrm{cfu} / \mathrm{g}$ in peppermint, $8.21 \times 10^{3} \mathrm{cfu} / \mathrm{g}$ in cinnamon, $4.37 \times 10^{4} \mathrm{cfu} / \mathrm{g}$ in oregano, whereas unpackaged samples were $7.82 \times 10^{3}$ $\mathrm{cfu} / \mathrm{g}$ in red pepper, $7.62 \times 10^{3} \mathrm{cfu} / \mathrm{g}$ in black pepper, $4.35 \times 10^{4} \mathrm{cfu} / \mathrm{g}$ in peppermint, $5.54 \times 10^{3} \mathrm{cfu} / \mathrm{g}$ in cinnamon, $4.21 \times 10^{4} \mathrm{cfu} / \mathrm{g}$ in oregano. Salmonella spp. was not found in any of the samples. When comparing the mold-yeast content of packaged and unpackaged samples, the difference in the level of contamination between the two groups did not show statistical significance ( $p>0.01$ ). Mold-yeast results of unpackaged red pepper, black pepper, peppermint, oregano, and packaged peppermint and oregano were above the maximum limits of Turkish Food Codex (TFC). Therefore, controlling mold and yeast content at the selling point is recommended.
\end{abstract}

Keywords: spice, contamination, mold, yeast, Salmonella spp.

\section{INTRODUCTION}

Spices are used in many areas in the food industry. They may undergo microbial contamination that may threaten human health due to inadequate or unhygienic conditions at the stages of collection, processing, and storage ${ }^{1,2}$. The contamination may occur from the soil, air, and water during collection and drying or due to animal waste in the environment, as well as using contaminated equip-

\footnotetext{
${ }^{*}$ Corresponding Author:

Ayse Humeyra Islamoglu

Phone number: +90216 7775727

E-mail address: humeyra.bicer@gmail.com

ORCIDs:

Ayşe Hümeyra İslamoğlu: 0000-0002-2138-5996

Burcu İrem Omurtag Korkmaz: 0000-0001-7918-6212

(Received 03 July 2020, accepted 13 July 2020)
} 
ment during production ${ }^{3}$. These can lead to contamination of spices with microorganisms like Salmonella sp. mold and yeast ${ }^{1}$. Especially some types of mold and yeast can produce mycotoxins that cannot be degraded by cooking and threaten human health ${ }^{5}$.

Molds are capable to produce mycotoxins easily at room temperatures ranging from $25^{\circ} \mathrm{C}$ to $30^{\circ} \mathrm{C}$ and moisture contents of above $16 \%^{5}$. These toxins, which are generally effective even in trace amounts, can cause chronic diseases or acute deaths ${ }^{6}$. Inappropriate storage directly affects the risk of mycotoxin proliferation, particularly, if spices were formerly contaminated with molds. Thus, monitoring of mold-yeast content at the selling point is critical to prevent from unhygienic storage. In former regulation of Turkish Food Codex moldyeast content of spices has been limited as $1 \times 10^{4} \mathrm{cfu} / \mathrm{g}^{7}$, whereas this limit is discarded in current regulation ${ }^{8}$. However, the International Food Standards of Codex Alimentarius Commission still suggests a maximum limit of $1 \times 10^{3} \mathrm{cfu} / \mathrm{g}$ for mold-yeast in spices ${ }^{9}$.

Besides the risk of mycotoxin related to mold-yeast contamination, Salmonella sp. contaminations, and related outbreaks were reported in spices, e.g. in black pepper ${ }^{10}$. Salmonella sp. is an important foodborne pathogen and most of the regulations suggest its absence in a food sample. According to the current microbiological criteria for spices in Turkish Food Codex ${ }^{8}$, Salmonella should not exist in $25 \mathrm{~g}$ of sample, as well as in the International Food Standards, Codex Alimentarius Commission suggests the absence of Salmonella in spice ${ }^{9}$.

Traditionally, spices are added in most of the Turkish foods. It has been determined that approximately 95\% of people in Turkey use spices to increase flavor, to enhance the smell and appearance, and to make the dishes appetizing ${ }^{11}$. Three most commonly used spices in the country were red pepper, black pepper, and peppermint, respectively ${ }^{12}$. However, the humidity of the climate in Turkey promotes the growth of mold and yeast in spices. Therefore, monitoring of the safety of spices seems to be important for the country.

As a consequence, the risk of microbial contamination in spices, this study aimed to investigate Salmonella spp. and the mold-yeast contents of five commonly used spices including; red pepper, black pepper, peppermint, cinnamon, oregano and compare the results of packaged and unpackaged ones. Limits set in the Turkish Food Codex (TFC) and Codex Alimentarius (CA) were also considered for the assessment of results. 


\section{METHODOLOGY}

\section{Sampling collection}

A total of 30 spice samples in unpacked $(n=15)$ and packaged $(n=15)$ form including red pepper (dried-ground), black pepper (powder), peppermint (driedleaves), cinnamon (powder), and oregano (dried-leaves) were obtained from markets and stores locating in İstanbul, in April 2019. All spices were collected as three samples from each spice and with a minimum amount of 50 grams. The analysis of the samples was carried out in the Basic Health Sciences Laboratory of Faculty of Health Sciences, Marmara University.

\section{Microbiological analyses}

To prepare the samples for analysis, five grams from each of three spices were mixed in sterile plastic bags. Hence, a total of a 15-gram sample mixture was obtained for each type of spice. Prepared sample mixture was diluted with 135 $\mathrm{ml}$ (1:9 ratio) of Peptone Water (PW, OXOID CM 009) for yeast-mold analyses and with Buffered Peptone Water (BPW, OXOID CM0509) for Salmonella spp. enrichment. Tenfold serial dilutions were prepared from the homogenized samples with PW for yeast-mold analyses. $0.1 \mathrm{ml}$ of each sample was taken to the petri dishes containing Dichloran Rose Bengal Chloramphenicol Agar (DRBC, OXOID CM 727) and cultivated with the spread plate method. Samples incubated for 5 days at $25^{\circ} \mathrm{C}$, aerobically. Yeast and mold colonies were enumerated after incubation.

For the enrichment of Salmonella spp., homogenized samples were incubated at $37^{\circ} \mathrm{C}$ for 24 hours, aerobically. Thereafter, Xylose Lysine Deoxycholate Agar (XLD, Merck Nr.1.05287) was used for Salmonella analyses. $0.1 \mathrm{ml}$ of homogenized samples were cultivated with the spread plate method. Petri dishes were incubated at $37^{\circ} \mathrm{C}$ for 24 hours, aerobically. Salmonella spp. determination was based on the formation of typical black centered red colonies in petri dishes.

The number of colonies counted as a result of microbiological analysis and calculated as the colony forming unit (cfu)/g and compared with the limits specified in Turkish Food Codex ${ }^{7,8}$ and Codex Alimentarius ${ }^{9}$.

\section{Statistical analyses}

Tenfold transformations were applied to all counts and statistical analyses were conducted using Microsoft Excel. A possible relationship between the colony count found in the packaged and unpackaged spices was analyzed by using the t-test. 


\section{RESULTS and DISCUSSION}

According to the results of this study, all of the samples (100\%) were contaminated with mold and yeast at different levels. Salmonella spp. was not detected in any of the samples. Mold and yeast growth in packaged spices were slightly lower than that of unpackaged ones, as shown in Table 1. However, this difference in the level of mold-yeast contamination between the two groups did not show statistical significance ( $\mathrm{p}>0.05)$.

Table 1. Microbiological content of spice samples

\begin{tabular}{|c|c|c|c|c|}
\hline \multirow[b]{2}{*}{ Spices } & \multicolumn{2}{|c|}{ Mold-yeast count (cfu/g) } & \multicolumn{2}{|c|}{ Salmonella spp. $(+/-)^{*}$} \\
\hline & $\begin{array}{c}\text { Packaged } \\
(n=15)\end{array}$ & $\begin{array}{l}\text { Unpackaged } \\
(n=15)\end{array}$ & $\begin{array}{c}\text { Packaged } \\
(n=15)\end{array}$ & $\begin{array}{l}\text { Unpackaged } \\
(n=15)\end{array}$ \\
\hline Red pepper $(n=6)$ & $7.82 \times 10^{3}$ & $1.07 \times 10^{4}$ & - & - \\
\hline Black pepper $(n=6)$ & $7.62 \times 10^{3}$ & $1.75 \times 10^{4}$ & - & - \\
\hline Peppermint $(n=6)$ & $4.35 \times 10^{4}$ & $7.72 \times 10^{4}$ & - & - \\
\hline Cinnamon $(n=6)$ & $5.54 \times 10^{3}$ & $8.21 \times 10^{3}$ & - & - \\
\hline Oregano $(n=6)$ & $4.21 \times 10^{4}$ & $4.37 \times 10^{4}$ & - & - \\
\hline Frequency & $100 \%$ & $100 \%$ & - & - \\
\hline $\mathrm{p}$ value & \multicolumn{2}{|c|}{0.076} & & \\
\hline
\end{tabular}

*-.. no visible colony was found

When the results are compared with the reliable limits in current microbiological criteria for spices of Turkish Food Codex (TFC, 2013), the absence of Salmonella is required, which is compatible with our results. This finding indicates that Salmonella contents of the samples in our study were within acceptable limits according to TFC-2013 ${ }^{8}$.

Mold-yeast content among the packaged spices, red pepper, black pepper, and cinnamon were below the former Turkish Food Codex (remarked as $1{\mathrm{X} 1 \mathrm{O}^{4}}^{4}$ $\mathrm{cfu} / \mathrm{g}$ in TFC-2009) limits ${ }^{7}$. It was determined that the mold-yeast content in packaged and unpackaged peppermint and oregano samples were above the maximum limits according to both of the TFC-2009 ${ }^{7}$ and the CA ${ }^{9}$. Both the packaged and unpackaged cinnamon samples were above the maximum limit of CA ${ }^{9}$ but below the maximum limit of $\mathrm{TFC}-2009^{7}$ which among the unpackaged samples only cinnamon was lower than this.

In a study conducted by Kizıl and colleagues with the unpackaged black peppers taken from several cities of Turkey including İstanbul, Salmonella spp. was found only in black pepper samples taken from İstanbul and İzmir province, whereas found in red pepper samples taken from Samsun province ${ }^{13}$. In a study conducted in Brazil, the highest level of Salmonella sp. contamination 
was found in black pepper ${ }^{14}$, whereas in the United States, basil, black pepper, coriander, curry powder, garlic powder, oregano, paprika, and red pepper were contaminated with Salmonella ${ }^{15}$. On the other hand, Salmonella was not found in packaged and in unpackaged red peppers in different countries, such as in Turkey ${ }^{16,17}$, in Iran ${ }^{18}$, as well as in other packaged and unpackaged spices including black pepper, cinnamon, basil, turmeric, berbere in Ethiopia ${ }^{19}$, and also in any of the spices and herbs, including black pepper, oregano, and cinnamon in $J \operatorname{ordan}^{20}$. Similar to these studies, none of the spice samples were contaminated with Salmonella spp. in our study.

Studies in Turkey show similarities in mold-yeast results of spices, which are mostly contaminated at least half of the collected samples. Hampikyan and colleagues examined microbiological contamination of 420 spice samples from İstanbul markets, used in the meat industry in Turkey, and found around the $85 \%$ samples contaminated with yeast and/or mold ${ }^{21}$. In a study conducted by Coşkun, black pepper, red pepper, and cinnamon in Tekirdağ markets were examined, molds were detected in $55 \%$ of samples, and whereas only $27 \%$ of the samples were below the mold-yeast limit of TFC ${ }^{22}$. In Diyarbakır, $70 \%$ of black pepper and $60 \%$ of red pepper samples were contaminated with mold, whereas yeast contamination was $10 \%$ in black pepper and $50 \%$ in red pepper samples ${ }^{2}$. In Kahramanmaraş, $91.3 \%$ of the red pepper samples were positive in terms of mold and yeast, and the average colony number of mold and yeast was $4.8 \times 10^{5}$ cfu/g ${ }^{23}$. In Şanlıurfa, red pepper obtained from supermarkets, open markets and retail stores, was examined and the samples contaminated with mold were also consist of a high amount of mycotoxins (up to $86.01 \mathrm{~g} / \mathrm{kg}$ ), which exceeded the legal mycotoxin limit of $10 \mu \mathrm{g} / \mathrm{kg}$ set by the Turkish Food Codex ${ }^{24}$.

There is a high frequency of mold-yeast contamination of spices all around the world. In a study of Banerjee and Sarkar (2003), 97\% of the spices, including black pepper, red pepper, and cinnamon were contaminated with mold, whereas yeast was found in only one of cumin sample ${ }^{25}$. In a recent study conducted in Argentina, mold-yeast counts of Argentinian paprika was between $2 \times 10^{2}$ and $1.9 \times 10^{5} \mathrm{cfu} / \mathrm{g}$, in which some samples exceeded the reliable limits of international food regulations ${ }^{26}$. Fogele and colleagues analyzed several spices including curry, black pepper, cumin, clove, cinnamon, thyme, basil, rosemary, and found mold contents of spices sold in small sellers significantly higher than those of sold in supermarkets. Although in our study difference of packaged and unpackaged samples did not show statistical significance, the result of the study of Fogele and colleagues indicated that the environmental factors, production process, and place where spices sold are effective on the mold growth ${ }^{27}$. Current food security 
criteria in TFC-2013 recommend analyzing Salmonella, B.cereus, and coagulasepositive Staphylococci in spice samples, i.e. mold-yeast discarded ${ }^{8}$. Although mold and yeast might be destroyed by the cooking of spice, their toxins might be still present in food. On the other hand, mold and yeast content can be considered as a kind of indicator of their proper storage condition and their contamination at the market level is still important. Especially when consumers do not take care of appropriate storage conditions at home, previously contaminated molds can grow easily and mycotoxins might be produced even at home. Therefore, at least controlling mold and yeast content at the selling point is a critical step to minimize the risk of mycotoxin exposure via consumption of spices.

In this study Salmonella sp. and mold-yeast content of packaged and unpackaged spices were investigated. Although Salmonella sp. was not detected in any of the samples, all of the samples were contaminated with mold-yeast. It has been observed that mold-yeast contamination in red pepper and black pepper samples is close to the maximum level of TFC, and both packaged and unpackaged peppermint and oregano samples were above the reliable limits. These findings are conforming with other studies in Turkey and also in other countries. Nevertheless, mold-yeast contamination in this study highlights particularly the necessity of monitoring frequently consumed spices and related mycotoxin analyses for estimation of the risk of exposure to mycotoxin via consumption in a portion.

\section{ACKNOWLEDGEMENT}

We thank our students Bilge Kılıç, Merve Karayiğit and Rana Elif Işık who helped us during the collection and analysis of the samples and the Head of the Basic Health Sciences Laboratory Prof. Dr. Ayşen Gargılı Keleş for her valuable support.

\section{CONFLICT OF INTEREST}

The authors declare that they have no conflicts of interest. 


\section{REFERENCES}

1. Schweiggert, U., Reinhold, C., Schieber, A. (2007). Conventional and alternative processes for spice production - a review. Trends Food Sci. Tech. 18, 260-268.

2. Vural, A., Arserim Kaya, N. B., Mete, M. (2004). Bazı öğütülmüş baharatlarda küf ve maya florasının incelenmesi. Dicle Univ. Tip Fakul. Derg. 31, 15-19.

3. Yllmaz, H., Şanlıer, N. (2014). Baharat Işınlama. Glda. 39, 111-118.

4. Milani, J., Maleki, G. (2014). Effects of processing on mycotoxin stability in cereals. J. Sci. Food Agric. 94, 2372-2375.

5. Thanushree, M. P., Sailendri, D., Yoha, K. S., Moses, J. A., Anandharamakrishnan, C. (2019). Mycotoxin contamination in food: an exposition on spices. Trends Food Sci. Tech. 93, 69-80

6. Yentür, G., Er, B. (2011). Gıdalarda aflatoksin varlığının değerlendirilmesi. Turk Hij. Den. Biyol. Derg. 69, 41-52

7. Turkish Food Codex (TFC). (2009). Türk Gida Kodeksi Mikrobiyolojik Kriterler Tebliği. Turkish Republic, Official Gazette, Nr. 27133

8. Turkish Food Codex (TFC). (2013). Türk Gıda Kodeksi Baharat Tebliği. Turkish Republic, Official Gazette, Nr. 28614.

9. Codex Alimentarius Commission (CA). (2003). Joint FAO/WHO, food standards programme FAO/WHO coordinating committee for the Near East. Second Session. Cairo, Egypt, 11 .

10. Codex Alimentarius Commission (CA). (2003). Joint FAO/WHO, food standards programme FAO/WHO coordinating committee for the Near East. Second Session. Cairo, Egypt, 11 .

11. Demircioğlu, Y., Yaman, M., Şimşek, I. (2007). Kadınların baharat kullanım alışkanlıkları üzerine bir araştırma. TAF Preventive Medicine Bulletin. 6, 161-168.

12. Kılıçhan, R., Çalhan, H. (2015). Mutfakların sihri baharat: Kayseri ilinde baharat tüketim alışkanlıklarının belirlenmesine yönelik bir çalışma. Journal of Tourism and Gastronomy Studies. 3, 40-47.

13. Kızıl, M., Wassouf, N., Metin, M. M. T., Gümüş, D., Dikmen, D., Uyar, M. F. (2015). Açıkta satılan baharatlarda Escherichia coli $\mathrm{O} 157: \mathrm{H} 7$ ve Salmonella spp. varlı̆̆ının moleküler mikrobiyojik analiz yöntemi ile belirlenmesi. Beslenme ve Diyet Dergisi. 43, 228-236.

14. Moreira, P. L., Lourencao, T. B., Pinto, J. P., Rall, V. L. (2009). Microbiological quality of spices marketed in the city of Botucatu, Sao Paulo, Brazil. J. Food Prot. 2, 421-424.

15. Zhang, G., Hu, L., Pouillot, R., Tatavarthy, A., Van Doren, J. M., Kleinmeier, D., Ziobro, G. ....\& Hammack, T. S. (2017). Prevalence of Salmonella in 11 spices offered for sale from retail establishments and in imported shipments offered for entry to the United States. J. Food Prot. $80,1791-805$.

16. Kimiran-Erdem, A., Arslan-Aydoğdu E. Ö., Gürün, S. (2013). Bacteriological analysis of the red pepper spices marketed as packaged and unpackaged in Istanbul. IUFS J. Biol. 72, 23-30

17. Çalışkan, B. (20o8). İstanbul ilinde tüketime sunulan kırmızı biberlerin bazı patojenler, kimyasal ve toksikolojik maddeler yönünden incelenmesi üzerine bir araştırma, Yüksek Lisans Tezi, Gıda Mühendisliği Ana Bilim Dalı, Namık Kemal Üniversitesi, Tekirdağ. 
18. Salari, R., Najafi, M. H., Boroushaki, M. T., Mortazavi, S. A., Najafi, M. F. (2012). Assessment of the microbiological quality and mycotoxin contamination of Iranian red pepper spice. J. Agr. Sci. Tech. 14, 1511-1521.

19. Bedada, T. L., Derra, F. A., Gebre, S. G., Sima, W. G., Edicho, R. M., Maheder, R. F., Negassi T. Y., Asefa, Y. B. (2018). Microbial Evaluation of Spices in Ethiopia. Open Microbiol. J. 12, 422-429.

20. Dababneh, B. F. (2013). An innovative microwave process for microbial decontamination of spices and herbs. Afr. J. Microbiol. Res. 7, 636-645.

21. Hampikyan, H., Bingol, E. B., Colak, H., Aydin, A. (2009). The evaluation of microbiological profile of some spices used in Turkish meat industry. J. Food Agric. Environ. 7, 111-115.

22. Coşkun, F. (2010). Microbiological Characteristics of Some Spices Sold in Tekirdağ Markets. J. Tekirdag Agric. Fac. 7, 85-93.

23. Erdoğrul, Ö. T. (200o). Kahramanmaraş'ta satılan acı kırmızı pul biberin bazı mikrobiyolojik özellikleri. KSÜ Fen ve Mühendislik Dergisi. 3, 108-113.

24. Karaaslan, M., Arslanğray, Y. (2015). Aflatoxins B1, B2, G1, and G2 contamination in ground red peppers commercialized in Sanliurfa, Turkey. Environ. Monit. Assess. 187, 184.

25. Banerjee, M., Sarkar, P. K. (2003). Microbiological quality of some retail spices in India. Food Res. Int. 36, 469-474.

26. González, M. G. M., Romero, S. M., Arjona, M., Larumbe, A. G., Vaamonde, G. (2017). Microbiological quality of Argentinian paprika. Rev. Argent Microbiol. 49, 339-346.

27. Fogele, B., Granta, R., Valcin, O., Berzin A. (2018). Occurrence and diversity of Bacillus cereus and moulds in spices and herbs. Food Control. 83, 69-74 